\title{
Anatomy-Based navigation for ventriculostomy: Nasion-coronal suture distance measurement
}

\section{Ventrikülostomide anatomi temelli navigasyon: Nazion-Koronal sütür arası mesafe ölçümü}

\author{
Mevci Özdemir ${ }^{1}$, Ayhan Cömert ${ }^{2}$, Kevser Özdemir ${ }^{3}$, Gökmen Kahiloğulları ${ }^{4}$, Melih Bozkurt ${ }^{4}$, Ağahan Ünlü ${ }^{4}$,
} Hasan Cağlar Uğur ${ }^{4}$

\begin{abstract}
Objective: In this study we aimed to determine a landmark that can be measured through the skin with nasal mid-point (bregma) to coronal suture, and additionally an average value was calculated. We report, to our knowledge, the distance between the nasion-coronal sutures is reported for the first time in Turkish population.
\end{abstract}

Methods: The study included 30 craniums and 30 frontal bones. Each skull from midline nasal suture to coronal suture curved up at the distance was measured with tape measure.

Results: Mean values were determined. Nasal suture between coronal suture distance average 12,2 cm (min10,3 $\mathrm{cm}$, up to $13,5 \mathrm{~cm}$ ) were detected.

Conclusion: Nasal suture is an easily palpable area through the skin. A small incision is carried down through skin to bone at the spot $12 \mathrm{~cm}$ back from the nasion $3 \mathrm{~cm}$ lateral to the midline for ventricular drainage operation. This data provide practical information for neurosurgeon and is available everywhere. J Clin Exp Invest 2014; 5 (3): 368-370

Key words: Coronal suture, external ventricular drainage, hydrocephalus, subarachnoid hemorrhage, shunt infection

\section{INTRODUCTION}

Ventriculostomy is a daily exercise on a busy neurosurgical service. The frontal horn of the lateral ventricle is one selected target for the proximal catheter in ventricular shunting. As this procedure is often performed blindly, the intended target for catheter tip placement, anterior to the foramen of Monroe [1]. The most frequent indications in patient with hydro-

\section{ÖZET}

Amaç: Bu çalışmada nazion sınır olarak kullanılarak koronal sütür lokalizasyonu tespit edilmeye çalışılmıştır. Nazion-koronal sütür arası mesafe bildiğimiz kadarı ile Türk toplumunda ilk defa bu çalışma ile literatüre sunulmaktadır.

Yöntemler: Bu çalışmada 30 kranium ve 30 frontal kemik kullanıımıştır. Her bir kafatasında mezuro yardımı ile nazal sütürden koronal sütüre olan mesafe ölçülmüştür.

Bulgular: Nazal sütür-koronal sütür arası mesafe 12,2 cm (minimum 10,3-maksimum 13,5 cm) olarak tespit edildi.

Sonuç: Nazion cilt üzerinden kolayca palpe edilebilen bir işaret noktasıdır. Naziondan $12 \mathrm{~cm}$ posteriorda orta hattan $3 \mathrm{~cm}$ lateralde yapılacak küçük bir cilt insizyonu ile drenaj noktası kolayca tespit edilebilir. Bu bilgi beyin cerrahları için her zaman kullanabilecekleri pratik bir bilgi olarak literatüre sunulmaktadır.

Anahtar kelimeler: Koronal sütür, eksternal ventriküler drenaj, hidrosefali, subaraknoid kanama, şant enfeksiyonu

cephalus and intraventricular hemorrhage or whenever intracranial hypertension is expected to be a significant problem. Although ventriculostomy is the most basic and simplest neurosurgical applications, sometimes it can cause difficult complications, the most important of these is infection. Factors that predispose a patient with a ventriculostomy to developing ventriculomeningitis have been investigated extensively, but key factor in the management of

${ }^{1}$ Pamukkale University, Faculty of Medicine, Department of Neurosurgery, Denizli, Turkey

${ }^{2}$ Ankara University, Faculty of Medicine, Department of Anatomy, Ankara, Turkey

${ }^{3}$ Denizli State Hospital, Department of Infectious Diseases and Clinical Microbiology, Denizli, Turkey

${ }^{4}$ Ankara University, Faculty of Medicine, Department of Neurosurgery, Ankara, Turkey

Correspondence: Mevci Ozdemir,

Pamukkale University, Faculty of Medicine, Department of Neurosurgery, Denizli, Turkey Email: mevciozdemir@gmail.com 
catheter infections is prevention. With this study we aimed to find a landmark based anatomy to avoided unnecessary incisions and reducing catheter infections [2-9].

\section{METHODS}

This study was carried out Ankara University, Department of Anatomy, Neuroanatomy laboratory. The study included 30 craniums and 30 frontal bones. Specimens with gross deformities of this region were excluded from study. Measurements were made by a single investigator. The distance which nasal suture to coronal suture curved up from midline was measured with tape measure (Fig. 1,2,3).

\section{RESULT}

Nasal suture between coronal suture distance average $12.2 \mathrm{~cm}$ ( $\min 10.3 \mathrm{~cm}$, up to $13.5 \mathrm{~cm}$ ) were detected (Table 1).

Table 1. Diameters of Sutura nasalis-Sutura coronalis distance

\begin{tabular}{lcc}
\hline & Number & Distance $(\mathrm{cm})$ \\
\hline Calvarium & 30 & 12.1 \\
Frontal Bone & 30 & 12.1 \\
Minimum value & & 10.3 \\
Maximum value & 13,5 \\
Mean value & & 12.1 \\
\hline
\end{tabular}

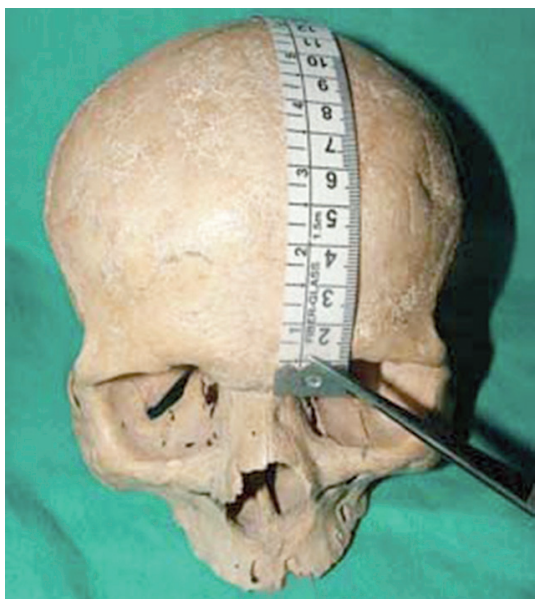

Figure 1. Antero-posterior view of nasion-coronal suture distance

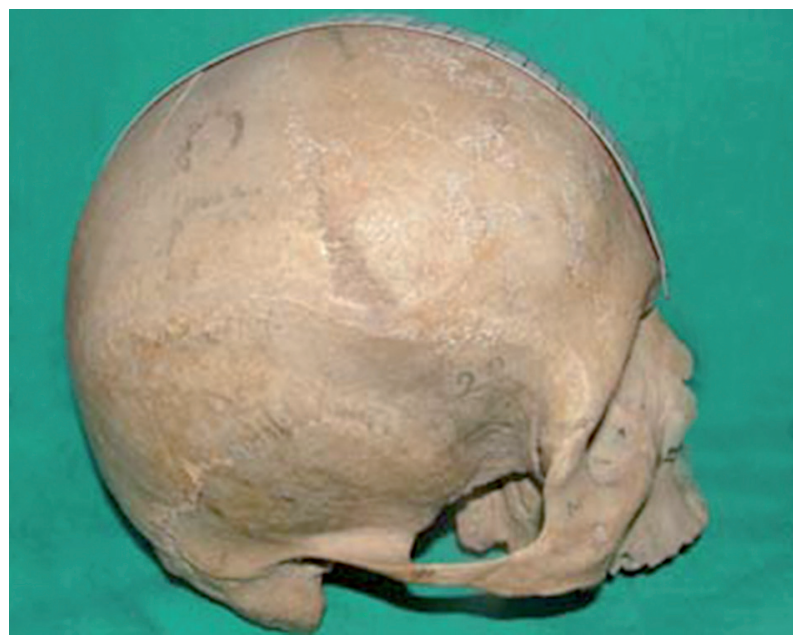

Figure 2. Lateral view of nasion-coronal suture distance

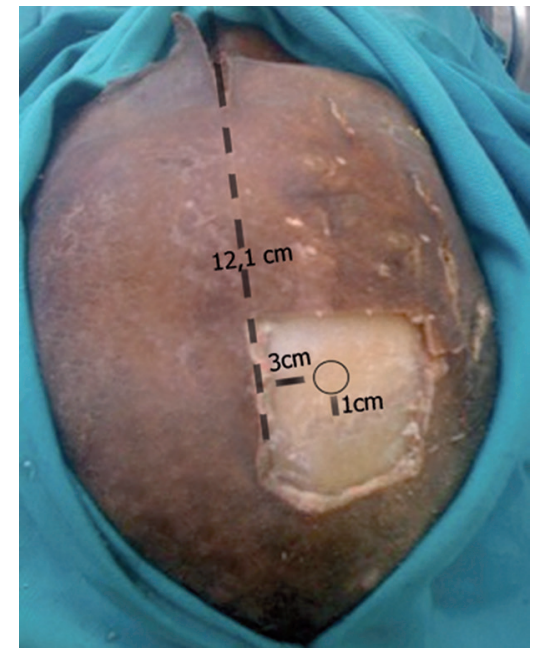

Figure 3. Kocher's point view on a cadaver specimen

\section{DISCUSSION}

Optimal skin incision for ventricular drainage placement is important. Coronal suture is used widely as a landmark for frontal horn is but identification of coronal suture may not be easy every time. To identify coronal suture localization, the use of nasioncoronal suture distance may prove to be beneficial. To this end, in our study an anatomy based navigation model for ventriculostomi was developed.

In the many of neurosurgical operative book's to find Kocher point, should be do palpable the coronal suture by hand (Fig.3). When we examine the literature, we find only one manuscript writing Dumm et al. about nasion-coronal suture distance. Dumm et al. report that a linear incision $10 \mathrm{~cm}$ behind the na- 
sion is located $1-2 \mathrm{~cm}$ in front of the coronal suture. We found $1 \mathrm{~cm}$ further away the before publication. The results of this study we believe that $11 \mathrm{~cm}$ away from the nasion and $3 \mathrm{~cm}$ lateral the midline a linear skin incision for ventriculostomy operation it easier to find in the coronal suture for Turkish population [7].

Especially younger neurosurgeons mostly used big skin incision. Nevertheless big skin incisions are commonly related the catheter infections. Catheter infection rates of increased the $22 \%$ have been reported in the literature. Majority of organisms responsible for catheter-related infections were skin flora $[10,11]$. Contamination of the ventricular catheter at the scalp tract overlying the drill site is thus a potentially important source of infections. With skin incision in the smallest possible level, subcutaneous tissue and the ventricular catheter parts fewer contact with the flora and primarily to prevent infection may be as many complications [12-21].

Placement of a ventricular catheter into the lateral ventricle is a routine procedure in the neurosurgical practice. Since the procedure is supposed to be easy to perform and it is mostly done by younger neurosurgeons in training. Nevertheless it is increased the incision line and infection rates. Awareness of the coordinates of the coronal suture according to the craniometrical points may considerably contribute to surgical intervention.

\section{REFERENCES}

1. Rajz G, Shooman D, Goren O, et al. Non-invasive repositioning of the ventricular catheter after suboptimal ventriculoperitoneal shunt placement. Acta Neurochir 2010;152:1435-1436.

2. Azeem SS, Origitano TC. Ventricular catheter placement with a frameless neuronavigational system: A 1-year experience. Neurosurg 2007;60:243-248.

3. Bauer DF, Tubbs RS, Satchivi LA. The Seldinger technique for ventricular catheter exchange: A technical note. Childs Nerv Syst 2008;24:753-755.

4. Daszkiewicz P, Barszcz S. Multiple shunt system revisions in patients with hydrocephalus - causes, effects, regularities and prognostic factors. Neurol Neurochir Pol. 2007;41:404-410.

5. Chrcanovic BR, Abreu MH, Custódio AL. A morphometric analysis of supraorbital and infraorbital foramina relative to surgical landmarks. Surg Radiol Anat 2011;33:329-335.

6. Cotton F, Rozzi FR, Vallee B, et al. Cranial sutures and craniometric points detected on MRI. Surg Radiol Anat 2005;27:64-70.
7. Dunn IF, Frerichs K, Day AL. Perioperative management of severe traumatic brain injuri in adults. In Schmidek HH, Roberts DW (eds), Operative Neurosurgical Techniques 5th edn. Philadelphia: Elsevier, 2006:31-44.

8. Ebeling U, Rikli D, Huber P, et al. The coronal suture, a useful bony landmark in neurosurgery? Craniocerebral topography between bony landmarks on the skull and the brain. Acta Neurochir 1987;89:130-134.

9. Hattapoğlu S, Hamidi C, Göya C, et al. Congenital bilateral perisylvian syndrome with hydrocephalus. J Clin Exp Invest 2012;3:552-554.

10. Annagür $A$, Altunhan $H$, Ertuğrul $S$, et al. A rare cause of neonatal meningitis: Group A streptococci. Dicle Med J 2013; 40:118-120.

11. Abuhandan M, Çalık M, Oymak $Y$, et al. Meningitis in children: Analysis of 92 cases. Dicle Med J 2013; 40:15-20.

12. Dickinson BP, Spoon DB, Cordray TL, et al. Correction of massive hydrocephalus and brain wound in holoprosencephaly. Craniofac Sur 2006;17:707-713.

13. Bafeltowska JJ, Buszman E, Mandat KM, et al. Therapeutic vancomycin monitoring in children with hydrocephalus during treatment of shunt infections. Surg Neurol 2004;62:142-150.

14. Lee CK, Tay LL, Ng WH, et al. Optimization of ventricular catheter placement via posterior approaches: A virtual reality simulation study. Surg Neurol 2008;70:274-277.

15. Oguz O, Sanli SG, Bozkir MG, et al. The pterion in Turkish male skulls. Surg Radiol Anat 2004;26:220224.

16. Pirotte B, James S, Lubansu A, et al. Sterile surgical technique for shunt placement reduces the shunt infection rate in children: preliminary analysis of a prospective protocol in 115 consecutive procedures. Childs Nerv Syst 2007;23:1251-1261.

17. Simon TD, Mayer-Hamblett N, Whitlock KB, et al. Few Patient, Treatment, and Diagnostic or Microbiological Factors, Except Complications and Intermittent Negative Cerebrospinal Fluid (CSF) Cultures During First CSF Shunt Infection, Are Associated With Reinfection. J Pediatric Infect Dis Soc 2014;3:15-22.

18. Sun $P$, Shin JH, Persing JA. Management of the ventricular shunt in posterior deformities of the skull in craniosynostosis. J Craniofac Surg 1997;8:38-41.

19. Thomale UW, Hosch $\mathrm{H}$, Koch $A$, et al. Perforation holes in ventricular catheters-is less more? Childs Nerv Syst 2010;26:781-789.

20. Tuli S, Hayon BO, Drake J, et al. Change in ventricular size and effect of ventricular catheter placement in pediatric patients with shunted hydrocephalus. Neurosurg 1999;45:1329-1333.

21. Villavicencio AT, Leveque JC, McGirt MJ, et al. Comparison of revision rates following endoscopically versus nonendoscopically placed ventricular shunt catheters. Surg Neurol 2003;59:375-379. 